\title{
Molecular markers associated with aluminium tolerance in Sorghum bicolor
}

\author{
Emily Jepkosgei Too', Augustino Osoro Onkware², Beatrice Ang'iyo Were', Samuel Gudu², Anders Carlsson ${ }^{3}$ \\ and Mulatu Geleta ${ }^{3^{*}}$
}

\begin{abstract}
Background: Sorghum (Sorghum bicolor, L. Moench) production in many agro-ecologies is constrained by a variety of stresses, including high levels of aluminium (Al) commonly found in acid soils. Therefore, for such soils, growing Al tolerant cultivars is imperative for high productivity.
\end{abstract}

Methods: In this study, molecular markers associated with Al tolerance were identified using a mapping population developed by crossing two contrasting genotypes for this trait.

Results: Four SSR (Xtxp34, S65_236, S66_34, and S66_342), one STS (CTG29_36) and three ISSR (811_1400, 835_200 and 884_200) markers produced alleles that showed significant association with Al tolerance. CTG29_36, 811_1400, Xtxp34 and Sb5_236 are located on chromosome 3 with the first two markers located close to Alt $t_{\text {SB, }}$ a locus that underlie the

Al tolerance gene (SbMATE) implying that their association with Al tolerance is due to their linkage to this gene. Although CTG29_36 and 811_1400 are located closer to Alt ${ }_{S B}, X$ Xxp34 and S65_236 explained higher phenotypic variance of Al tolerance indices. Markers 835_200, 884_200, Sb6_34 and Sb6_342 are located on different chromosomes, which implies the presence of several genes involved in Al tolerance in addition to SbMATE in sorghum.

Conclusion: These molecular markers have a high potential for use in breeding for Al tolerance in sorghum.

Keywords: Aluminium tolerance, Mapping population, Molecular markers, Net root length in aluminium, Sorghum bicolor

\section{Background}

Sorghum (Sorghum bicolor L. Moench), is a staple cereal in many parts of Africa and Asia where it is grown mostly on small-scale, resource poor holdings. Although it is a hardy cereal, its production is significantly reduced by aluminium ( $\mathrm{Al})$ stress, especially in the highly leached acidic soils $[1,2]$. Inhibition of root growth is the primary symptom of $\mathrm{Al}$ stress in plants $[3,4]$. The primary consequence of $\mathrm{Al}$ stress is a poorly developed root system that makes the crop vulnerable to drought and limited nutrient uptake [5] and ultimately reduced crop yields [6]. In Kenya, over $70 \%$ of sorghum is produced in the western and central regions. These areas are

\footnotetext{
* Correspondence: Mulatu.Geleta.Dida@slu.se

${ }^{3}$ Department of Plant Breeding, Swedish University of Agricultural Sciences,

P.O. Box 101, SE-230 53 Alnarp, Sweden

Full list of author information is available at the end of the article
}

characterized by acid soils [7] with $\mathrm{Al}$ percent saturation ranging from 4 to $46 \%$ [8]. Low sorghum grain yield in the country is partly attributed to acid soil stress [9] including $\mathrm{Al}$ toxicity. Therefore, there is the need to deploy $\mathrm{Al}$ tolerant sorghum cultivars in order to increase productivity.

Plant tolerance to aluminium stress is based on exclusion or internal mechanisms that enable $\mathrm{Al}$ to be tolerated once it has entered the plant cells $[10,11]$. Some plant species accumulate $\mathrm{Al}$ and complexed it with other substances to render it less toxic [12]. Al tolerant cultivars of sorghum and most other cereals use the $\mathrm{Al}$ exclusion mechanisms based mainly on secretion of organic acids, such as citrate, malate and oxalate that chelate $\mathrm{Al}$ outside the cells and thereby reduce its availability $[13,14]$. When exposed to $\mathrm{Al}$ stress, tolerant sorghum varieties reportedly secrete large quantities of

(C) The Author(s). 2018 Open Access This article is distributed under the terms of the Creative Commons Attribution 4.0 International License (http://creativecommons.org/licenses/by/4.0/), which permits unrestricted use, distribution, and 
citric acid [14], malic acid and trans-aconitic acids [15, 16]. Aluminium-induced exudation of organic acids in plant roots is mediated by anionic channels in the plasma membrane [12]. The plant genes involved in the Alinduced acid exudation are members of the aluminium activated malate transporter (ALMT) and the multi-drug and toxin extrusion (MATE) families that encode membrane transporter proteins $[14,17,18]$.

Although significant progress has been made in crop improvement through phenotypic selection for Al tolerance [5, 19-21], the testing procedures may be difficult and time consuming due to the effect of genotype by environment interactions for this trait. In this regard, molecular markers based screening procedure can be more efficient than the use of morphological markers in identifying $\mathrm{Al}$ tolerant sorghum genotypes.

Sorghum has significant genotypic variation for tolerance to $\mathrm{Al}[22,23]$, which can be exploited to breed genotypes with superior tolerance to Al stress. Significant progress has been made in developing genomic tools and resources related to aluminium tolerance in sorghum, including the development of some molecular markers that can be used for marker assisted selection [14, 23-27]. However, additional work has to be done through exploring global sorghum genetic resources to identify additional genomic regions that contribute to this trait and eventually develop sets of molecular markers that can be used to efficiently breed sorghum for $\mathrm{Al}$ tolerance.

An aluminium tolerance locus referred to as $A l t_{S B}$ was identified through comparative mapping procedure in sorghum [24]. This locus was later found to underlie SbMATE, a MATE family gene, which encodes a protein that is responsible for citric acid exudation [14]. Causative polymorphisms that include insertions and single nucleotide polymorphism (SNPs) that were positively correlated with aluminium tolerance have been identified within this gene [27]. STS markers designated as CTG29 and M181 have been reported to be closely linked to $A l t_{S B}$ at 0 . $2 \mathrm{cM}$ and $0 \mathrm{cM}$, respectively [14]. However, it was not known whether the sorghum population used in this study relied on $A t_{S B}$ or different Al tolerance gene(s). Conserved gene order in genomic regions harboring $\mathrm{Al}$ tolerance loci has been reported in members of the grass family [23]. Hence, with the availability of saturated genetic maps of major cereals, it is possible to identify markers linked to $\mathrm{Al}$ tolerance genes in sorghum that are orthologous to Al tolerance genes in other cereal crops. The present study was conducted to identify molecular markers associated with genes/QTLs that confer tolerance to aluminium toxicity in sorghum.

\section{Methods \\ Plant material and the development of the mapping population}

Two sorghum lines, Seredo and ICSR 110, were used to develop a mapping population for the identification of molecular markers associated with aluminium tolerance. Seredo is a popular but Al-sensitive commercial Kenyan sorghum with medium height and early maturity that is marketed by the Kenya Seed Company (MUSRT). ICSR 110 is an early maturing, medium height, Al-tolerant inbred line developed by International Crops Research Institute for the Semi-Arid Tropics (ICRISAT, Hyderabad, India). Seredo was used as a pollen recipient from ICSR 110 to develop the hybrid population that was advanced to $F_{3}$ by selfing. The mapping population comprised $229 \mathrm{~F}_{2: 3}$ progenies derived from $22 \mathrm{~F}_{2}$ plants, which in turn derived from three different $\mathrm{F}_{1}$ plants.

The $\mathrm{Al}$ tolerance of parental lines and $\mathrm{F}_{2: 3}$ progenies was evaluated according to the procedures described by Magalhaes et al. [24] using the basal nutrient solution of Magnavaca et al. [28]. A concentration of $148 \mu \mathrm{M} \mathrm{Al}$ was used to study the effect of aluminium on root growth of the seedlings based on recommendations from previous studies $[14,23]$. For this purpose, seeds were sterilized in 1\% hypochlorite and germinated on paper.

Since individual plants in $\mathrm{F}_{2: 3}$ population are not genetically identical, it was not possible to set up a separate control experiment. Hence, the following procedure was followed to determine the root growth of individual plants under a solution without $\mathrm{Al}$ (control solution) and under a solution containing $\mathrm{Al}$, as described in Caniato et al. [23] and Ringo et al. [29]. The two solutions have the same composition except that the latter contains $148 \mu \mathrm{M} \mathrm{Al}$. First, the seedlings were given a germination period of 4 days and the root length of each plant, which is referred to as initial root length under control solution $\left(\mathrm{il}_{\mathrm{c}}\right)$, was measured. Then, the seedlings were acclimated in a control nutrient solution for $24 \mathrm{~h}$ ( 1 day) and the root length of each plant, which is referred to as final root length under control solution $\left(\mathrm{fl}_{\mathrm{c}}\right)$, was measured. The seedlings were then transferred to a solution containing $148 \mu \mathrm{M} \mathrm{Al}$ and allowed to grow for 5 days and the root length of each plant, which is referred to as final root length under $\mathrm{Al}\left(\mathrm{fl}_{\mathrm{Al}}\right)$, was measured. Based on these measurements, the net root length of each plant under $\mathrm{Al}\left(\mathrm{NRL}_{\mathrm{Al}}\right)$ was calculated as $\mathrm{fl}_{\mathrm{Al}}-\mathrm{fl}_{\mathrm{C}}$, whereas the percent relative root growth of each plant under the $\mathrm{Al}$ solution as compared to the growth under the control solution (\%RRG) was calculated as $\left[\left(\mathrm{fl}_{\mathrm{Al}}-\mathrm{fl}_{\mathrm{c}}\right)_{5 \mathrm{~d}} /\left(\mathrm{fl}_{\mathrm{c}}-\mathrm{il}_{\mathrm{c}}\right)_{1 \mathrm{~d}} \times 5\right] \times 100$. The values of $\mathrm{NRL}_{\mathrm{Al}}$ and \%RRG were used to classify the $F_{2: 3}$ progenies into tolerant or sensitive groups. Leaves were sampled from the parents, $F_{1}$ and $F_{2: 3}$ seedlings for DNA extraction and marker analysis. 


\section{DNA extraction}

Genomic DNA was extracted separately from leaf tissue of each $F_{2: 3}$ seedling, parent and $F_{1}$ hybrid using a cetyltrimethyl ammonium bromide (CTAB) method, as described in Bekele et al. [30]. In total, DNA was extracted from six parental plants (three ICSR 110 and three Seredo) , three $\mathrm{F}_{1}$ and $229 \mathrm{~F}_{2: 3}$ plants. The DNA quality and concentration were assessed using a Nanodrop ${ }^{\circ}$ ND-1000 spectrophotometer (Saveen \& Werner ${ }^{\oplus}$ Malmö, Sweden) and by ethidium bromide staining following electrophoresis on $1.5 \%$ agarose gel.

\section{PCR amplification of ISSR, SSR and STS markers}

Fifty (50) inter-simple sequence repeat (ISSR) primers, twenty four (24) simple sequence repeat (SSR) primerpairs and two (2) sequence tagged site (STS) primerpairs were tested on $\mathrm{Al}$ tolerant and sensitive parental lines to identify potential markers linked to Al tolerance.

The 50 ISSR primers were selected for screening, as they generated clear and well-separated banding pattern suitable for detecting polymorphism. The ISSR amplification reaction was performed in a total volume of $25 \mu \mathrm{l}$

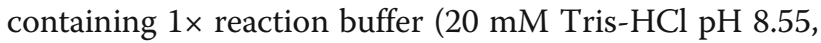
$16 \mathrm{mM}\left(\mathrm{NH}_{4}\right) \mathrm{SO}_{4}, 0.01 \%$ Tween 20 and $\left.2 \mathrm{mM} \mathrm{MgCl}_{2}\right)$, $0.4 \mu \mathrm{M}$ primer, $0.2 \mathrm{mM}$ dNTPs, $0.5 \mathrm{U}$ Taq DNA polymerase and $10 \mathrm{ng}$ of sample DNA. Amplifications were carried out using GeneAmp ${ }^{\circledR}$ PCR System 9700 (Applied Biosystems) with an initial denaturation step at $94{ }^{\circ} \mathrm{C}$ for 1 min followed by 40 cycles of $94{ }^{\circ} \mathrm{C}$ for $1 \mathrm{~min}, 55^{\circ} \mathrm{C}$ for $2 \mathrm{~min}$ and $72{ }^{\circ} \mathrm{C}$ for $18 \mathrm{~s}$; and a final extension step at $72{ }^{\circ} \mathrm{C}$ for $5 \mathrm{~min}$.

The 24 SSR markers were selected based on their representation of all sorghum chromosomes and their previously reported high polymorphism. The PCR amplification of SSR loci was performed in a $25 \mu$ l reaction mixture containing $25 \mathrm{ng}$ of template DNA, $1 \times$ PCR buffer [20 mM Tris- $\mathrm{HCl}(\mathrm{pH} 8.55), 16 \mathrm{mM}\left(\mathrm{NH}_{4}\right)_{2} \mathrm{SO}_{4}$, $0.01 \%$ Tween 20 and $2 \mathrm{mM} \mathrm{MgCl}_{2}$ ], $0.3 \mathrm{mM}$ dNTPs, 0 . $25 \mu \mathrm{M}$ of each primer, and $1 \mathrm{U}$ Taq DNA polymerase (Saveen \& Werner ${ }^{\circ}$, Sweden). The PCR reactions employed a touchdown PCR method [31] and were run using an Eppendorf AG-22331 Thermal Cycler (Hamburg, Germany) after optimizing annealing temperatures for the individual primer-pairs. The amplification profiles consisted of initial denaturation of the template DNA at $95{ }^{\circ} \mathrm{C}$ for $3 \mathrm{~min}$, followed by 10 cycles at $95{ }^{\circ} \mathrm{C}$ for $30 \mathrm{~s}, 60{ }^{\circ} \mathrm{C}$ or $65{ }^{\circ} \mathrm{C}$ (depending on the primer-pair) for $30 \mathrm{~s}$ (with a decrease of $1{ }^{\circ} \mathrm{C} /$ cycle) and $72{ }^{\circ} \mathrm{C}$ for $45 \mathrm{~s} ; 30$ cycles at $94{ }^{\circ} \mathrm{C}$ for $30 \mathrm{~s}, 50{ }^{\circ} \mathrm{C}$ or $55^{\circ} \mathrm{C}$ (depending on the primer-pair) for $30 \mathrm{~s}$ and $72{ }^{\circ} \mathrm{C}$ for $45 \mathrm{~s}$, and a final extension for $20 \mathrm{~min}$ at $72{ }^{\circ} \mathrm{C}$.

The two STS markers (CTG29 and M181) are tightly linked to $A l t_{S B}$, the locus that underlies SbMATE Al tolerance gene $[14,23]$. The primers used for the amplification of these markers were those published by Caniato et al. [23]. The PCR reactions for STS markers were run in a GeneAmp ${ }^{\circledR}$ PCR System 9700 Thermal Cycler (Applied Biosystems) in a $20 \mu \mathrm{l}$ reaction mixture containing $30 \mathrm{ng}$ of DNA template, $1 \times$ PCR buffer [20 mM Tris- $\mathrm{HCl}\left(\mathrm{pH}\right.$ 8.55), $16 \mathrm{mM}\left(\mathrm{NH}_{4}\right)_{2} \mathrm{SO}_{4}, 0.01 \%$ Tween 20 and $2 \mathrm{mM} \mathrm{MgCl}_{2}$ ], $0.5 \mathrm{mM}$ dNTPs, $1.9 \mathrm{mM}$ $\mathrm{MgCl}_{2}, 0.11 \mu \mathrm{M}$ of each primer and $1 \mathrm{U}$ Taq DNA polymerase. The PCR program consisted of an initial DNA denaturation step of $1 \mathrm{~min}$ at $95{ }^{\circ} \mathrm{C}$ followed by 30 cycles of denaturation at $95{ }^{\circ} \mathrm{C}$ for $30 \mathrm{~s}$, annealing at $55^{\circ} \mathrm{C}$ (for M181) or $57{ }^{\circ} \mathrm{C}$ (for CTG29) for 1 min, extension at $72{ }^{\circ} \mathrm{C}$ for $1 \mathrm{~min}$, followed by a final extension step at $72{ }^{\circ} \mathrm{C}$ for $5 \mathrm{~min}$. In the case of CTG29, additional $2 \mathrm{mM} \mathrm{MgCl}_{2}$ was used in the reaction mixture, and 40 cycles of amplification at annealing temperature of $58{ }^{\circ} \mathrm{C}$ was used.

\section{Electrophoresis, staining, visualization and polymorphism survey}

The PCR products were separated on 1.5\% agarose gel containing ethidium bromide to confirm amplification and thereafter visualized and photographed using a UV photo print system (IP-215-SD) fitted with a Sony ${ }^{\bullet}$ XST50CE camera (Saveen \& Werner, Sweden). For both ISSR and SSR markers, the PCR products were then electrophoresed on polyacrylamide gels (CleanGel 10\% 52S; ETC Electrophorase-technik ${ }^{\oplus}$, Germany) for better resolution and silver-stained, as described by Geleta and Bryngelsson [32].

A marker polymorphism survey of the parents was done and the markers that differentiated the two parents were used to genotype the F2:3 progenies. The $\mathrm{F}_{1} \mathrm{~s}$ were included in the analysis as positive controls. Three ISSR primers, four SSR and one STS primer-pairs generated promising markers (Table 1). Two of the three selected polymorphic ISSR markers were converted to sequence characterized amplified region (SCAR) markers as described below.

\section{Development and analysis of SCAR markers}

Two DNA fragments of approximately $1400 \mathrm{bp}$ and $200 \mathrm{bp}$ long that were amplified by ISSR_811 and ISSR_884 primers, respectively, were identified as co-segregating with aluminium tolerance. In this paper, these fragments are referred to as 811_1400 and 884_200, respectively. Both fragments were recovered from gels for cloning and sequencing. The 811_1400 fragment was purified from agarose gel using QIAquick ${ }^{\circ} \mathrm{Gel}$ extraction and purification kit (QIAGEN GmbH, Germany) according to the manufacturer's instructions. The purified DNA was used in the subsequent cloning of the marker fragment.

The 884_200 fragment was not clearly resolved on agarose gel and hence the PCR products were separated on polyacrylamide gel and then recovered following the procedure described by Sanguinetti [33]. The fragments 
Table 1 List of primers/primer-pairs used to amplify markers that showed association with Al tolerance in sorghum

\begin{tabular}{|c|c|c|c|c|c|}
\hline Marker type & Locus name & Primer sequences $\left(5^{\prime}-3^{\prime}\right)$ & Repeat motif & Fragment size range (bp) & $\mathrm{T}_{\mathrm{a}}\left({ }^{\circ} \mathrm{C}\right)$ \\
\hline \multirow[t]{3}{*}{ ISSR } & ISSR_811 & F/R: GAG AGA GAG AGA GAG AC & - & 1400 & 55 \\
\hline & ISSR_835 & F/R: AGA GAG AGA GAG AGA GCT C & - & Ca. 200 & 55 \\
\hline & ISSR_884, & F/R: HBH ATC AGA GAG AGA GAG AG & - & Ca. 200 & 55 \\
\hline \multirow[t]{4}{*}{ SSR } & Sb5_236 & $\begin{array}{l}\text { F: GCC AAG AGA AAC ACA AAC AA } \\
\text { R: AGC AAT GTA TाT AGG CAA CAC A }\end{array}$ & $(A G)_{20}$ & 160-208 & 55 \\
\hline & $S b 6 \_342^{b}$ & $\begin{array}{l}\text { F: TGC TTG TGA GAG TGC CTC CCT } \\
\text { R: GTG AAC CTG CTG CTT TAG TCG ATG }\end{array}$ & $(\mathrm{AC})_{25}$ & $270-294$ & 50 \\
\hline & $S b 6 \_34^{b}$ & $\begin{array}{l}\text { F: AAC AGC AGT AAT GCC ACA C } \\
\text { R: TGA CTT GGT AGA GAA CTT GTC TTC }\end{array}$ & {$[(\mathrm{AC}) /(\mathrm{CG})]_{15}$} & $188-208$ & 55 \\
\hline & $x \operatorname{txp} 34^{c}$ & $\begin{array}{l}\text { F: TGG TTC GTA TCC TTC TCT ACA G } \\
\text { R: CAT ATA CCT CCT CGT CGC TC }\end{array}$ & $(\mathrm{CT})_{29}$ & 365 & 55 \\
\hline \multirow[t]{3}{*}{ STS } & CTG29 d,e & $\begin{array}{l}\text { F: ATG CAG TAT CTG CAG TAT CAT TT } \\
\text { R: AAT CCG TCA GGT CAG CAA TC }\end{array}$ & - & $226-228$ & 57 \\
\hline & $M 181^{\mathrm{d}, \mathrm{e}}$ & $\begin{array}{l}\text { F: AAG GCA ACA ACT GAG GCA CT } \\
\text { R: TCG CTA GAG TGG TGC AAG AA }\end{array}$ & - & $169-174$ & 55 \\
\hline & CTG29_36 f,g & $\begin{array}{l}\text { F: TGG TGA TAT TAT TAA AAC TGT GTT A } \\
\text { R: AAT CCG TCA GGT CAG CAA TC }\end{array}$ & - & 200 & 58 \\
\hline \multirow[t]{2}{*}{ SCAR } & SCAR_81 $811^{\mathrm{h}}$ & $\begin{array}{l}\text { F: ACG CAA GTT CCG AGG AGA A } \\
\text { R: GAG AGA GAG AGA GAG ACA GAG GTT GTC }\end{array}$ & - & 1119 & 65 \\
\hline & $S C A R \_884^{h}$ & $\begin{array}{l}\text { F: AGA GAG AGA GAG AGC TCA CAC A } \\
\text { R: AGA GAG AGA GAG AGG TGT TाT A }\end{array}$ & - & 226 and 446 & 61 \\
\hline
\end{tabular}

${ }^{a}$ Source: University of British Columbia, Canada: http://www.scribd.com/doc/23812434/UBC

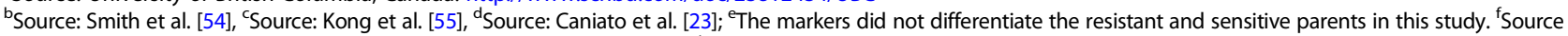
of forward primer: this study; ${ }^{9}$ Source of reverse primer: Caniato et al. [23]; ${ }^{\mathrm{h}}$ Source: this study. $\mathrm{F}=$ Forward; $\mathrm{R}=\mathrm{Reverse}$; $\mathrm{F} / \mathrm{R}=\mathrm{used}$ as both forward and reverse primers.

'In the primer sequence of ISSR_884, B $=\mathrm{C}$ or $\mathrm{G}$ or $\mathrm{T}$ whereas $\mathrm{H}=\mathrm{A}$ or $\mathrm{C}$ or $\mathrm{T}$

were extracted from agarose or polyacrylamide gels in $100 \mu \mathrm{l}$ of extraction buffer $(10 \mathrm{mM}$ Tris- $\mathrm{HCl}, 50 \mathrm{mM}$ $\mathrm{KCl}, 1.5 \mathrm{mM} \mathrm{MgCl}_{2}, 0.1 \%$ Triton $\left.{ }^{\odot} \mathrm{X}-100, \mathrm{pH} 9.0\right)$ by incubation at $95{ }^{\circ} \mathrm{C}$ for $20 \mathrm{~min}$. One microliter of the extracted DNA solution was used to re-amplify the target fragment using Advantage ${ }^{\oplus}$ HF2 Taq polymerase (Invitrogen) according to the ISSR amplification procedures describe above. An aliquot of the PCR products was analysed on agarose gel to confirm amplification and the rest purified using QIAquick ${ }^{\ominus}$ PCR purification kit (QIAGEN GmbH, Germany). The purified DNA fragments were ligated into pJET1.2/blunt cloning vector following the sticky-end cloning protocol as outlined in the CloneJET ${ }^{m}$ PCR Cloning Kit instruction manual (Fermentas ${ }^{\oplus}$, Life Sciences).

Transformation of chemically competent Escherichia coli cells (One Shot ${ }^{\ominus}$ TOP10-Invitrogen) was done following the manufacturer's instructions. Single colonies of transformed cells were picked and analyzed by colony PCR using pJET1.2 primer-pairs to identify clones that carried the fragments of interest. These clones were subcultured in liquid Luria Bertini (LB) media containing ampicillin $(100 \mu \mathrm{g} / \mathrm{ml})$ for plasmid mini-preparations. Plasmid DNA was purified using QIAprep ${ }^{\circ}$ spin miniprep kit (QIAGEN GmbH, Germany) as described by the manufacturer.
Plasmid DNA harbouring the inserts was digested with Bgl11 restriction endonuclease to confirm fragment size. Samples that had the desired inserts were sequenced using one of the pJET1.2 primers. The sequence quality was checked using Sequence Scanner v. 1.0 (Applied Biosystems ${ }^{\odot}$ ) and sequence alignment was done with ClustalX v. 2 [34]. The aligned sequences were manually edited using BioEdit@ version 7.0 [35].

The sequences of the $811 \_1400$ and $884 \_200$ fragments were used to design new primers to amplify SCAR markers SCAR_811 and SCAR_884, respectively. Primers were designed by extending the ISSR primers so that the 3 '-end of the primers contain SNPs that differentiated the tolerant and sensitive sorghum genotypes. Primer3 (an online primer designing program (http://primer3.ut.ee) was also used to design alternative primers. Different combinations of primers were tested for optimal amplification of the corresponding SCAR markers.

The PCR for SCAR_884 was performed in a volume of $50 \mu \mathrm{l}$ containing $50 \mathrm{ng}$ of template DNA, $1 \times$ PCR buffer, $3.5 \mathrm{mM} \mathrm{MgCl}_{2}, 0.1 \mathrm{mM}$ dNTPs, $0.5 \mu \mathrm{M}$ of each primer and $1 \mathrm{U}$ of Taq DNA polymerase. The reactions were carried out in GeneAmp ${ }^{\circ}$ PCR System 9700 Thermal Cycler with an initial denaturation step at $94{ }^{\circ} \mathrm{C}$ for $3 \mathrm{~min}$, followed by 30 cycles at $94{ }^{\circ} \mathrm{C}$ for $1 \mathrm{~min}, 61^{\circ} \mathrm{C}$ for $1 \mathrm{~min}$, and $72{ }^{\circ} \mathrm{C}$ for $2 \mathrm{~min}$, followed by final 
extension step at $72{ }^{\circ} \mathrm{C}$ for $7 \mathrm{~min}$. The reaction mixtures and PCR conditions for SCAR_811 were similar to those of SCAR_884 except that the concentration of $\mathrm{MgCl}_{2}$ was $2 \mathrm{mM}$ and the annealing temperature was $65^{\circ} \mathrm{C}$.

\section{Data scoring and statistical analysis}

The bands for ISSR, STS and SCAR markers were scored as present (1) or absent (0) whereas the SSR marker fragments were scored as either parental allele (A or B),or heterozygous for both alleles (AB). All phenotypic data were subjected to analysis of variance (ANOVA) using $\mathrm{SPSS}^{\circ}$ and means were separated using Tukey's test at $5 \%$ significance level. The association of individual marker with $\mathrm{Al}$ tolerance was tested with oneway analysis of variance and linear regression analysis, with a threshold significance level of $P \leq 0.05$. When a significant difference was found between the genotypic groups, a pairwise comparison was made using Tukey's test. For those markers that showed significant association with aluminium tolerance when analyzed individually, multiple linear regression analysis was conducted to check for collinearity between the markers. The Chi-square goodness-of-fit test for the Mendelian segregation of the alleles of each marker was also conducted for the $\mathrm{F}_{2: 3}$ population (Table 2).

\section{Results}

\section{Response of parental lines and their progenies to} aluminium stress

The root growth in the two parental sorghum lines, Seredo and ICSR 110, exhibited significantly different responses $(p<0.05)$ to the $\mathrm{Al}$ stress at $148 \mu \mathrm{M} \mathrm{Al}$ (Figs. 1 and 2). ICSR 110 was tolerant with only $15 \%$ reduction in root growth, whereas Seredo had 53\% reduction in root growth. The net root growth in aluminium and percentage of relative root growth were strongly correlated $\left(r^{2}=0.70\right)$. Based on the variation in net growth of the sensitive parent, the $\mathrm{F}_{2: 3}$ progeny plants with net root growth of $4.0 \mathrm{~cm}$ or less were classified as sensitive. Those that had net root growth ranging between $4.0 \mathrm{~cm}$ and $5.0 \mathrm{~cm}$ were classified as moderately tolerant, while progeny plants with a net root growth above $5.0 \mathrm{~cm}$ were classified as tolerant to $\mathrm{Al}$ stress. Based on this criterion, among the $229 \mathrm{~F}_{2: 3}$ population, 98,58 and 73 individuals were tolerant, moderately tolerant and sensitive, respectively.

\section{The molecular markers associated with tolerance to Aluminium toxicity}

Ten of the fifty ISSR primers amplified fragments that were polymorphic between the two parental lines. Preliminary analysis of the ten polymorphic markers using $21 \mathrm{Al}$ tolerant and $21 \mathrm{Al}$ sensitive $\mathrm{F}_{2: 3}$ progeny revealed that ISSR_811, ISSR_835 and ISSR_884 primers amplified three fragments of approximately $1400 \mathrm{bp}, 200 \mathrm{bp}$ and $200 \mathrm{bp}$, respectively, having uneven distribution among aluminium tolerant and sensitive progenies. After genotyping, the remaining $187 \mathrm{~F}_{2: 3}$ progeny plants were genotyped with these primers. The analysis of phenotypic and genotypic data from the $229 \mathrm{~F}_{2: 3}$ progeny revealed significant association of these markers with tolerance to $\mathrm{Al}$ toxicity (Table 2). The 811_1400 fragment was specific to Seredo and found in most $\mathrm{Al}$ sensitive progeny. On the other hand, the 835_200 and 884_200 amplified fragments showed significant association with aluminium tolerance.

Table 2 Simple and multiple linear regression analysis of $229 F_{2: 3}$ progeny plants for the association between marker-based genotypes and net root length in aluminium $\left(N R L_{A l}\right)$ and percent relative root growth (\%RRG); and Chi-square goodness- of-fit test for Mendelian segregation of the markers

\begin{tabular}{|c|c|c|c|c|c|c|c|c|c|c|}
\hline \multirow[t]{2}{*}{ Marker } & \multirow[t]{2}{*}{${ }^{\mathrm{d}}$ Chromosome number } & \multirow[t]{2}{*}{${ }^{\mathrm{d}}$ Marker position (bp range) } & \multicolumn{3}{|l|}{$N R L_{A l}$} & \multicolumn{3}{|l|}{$\% R R G$} & \multicolumn{2}{|c|}{$x^{2}$ test } \\
\hline & & & $\mathrm{F}$ & $P$-value & $R^{2}$ & $\mathrm{~F}$ & $P$-value & $R^{2}$ & $x^{2}$ & $P$-value \\
\hline Sb5_236 & 3 & $52,278,272-52,278,445$ & 15.08 & 0.000 & 0.110 & 11.92 & 0.001 & 0.050 & 5.33 & 0.070 \\
\hline Xtxp34 & 3 & $69,704,047-69,704,411$ & 18.75 & 0.000 & 0.142 & 17.07 & 0.000 & 0.070 & 3.94 & 0.139 \\
\hline CTG29_3b & 3 & $70,939,651-70,939,834$ & 11.42 & 0.001 & 0.048 & 9.49 & 0.002 & 0.040 & 3.60 & 0.059 \\
\hline $811 \_1400^{\mathrm{a}}$ & 3 & $71,473,923-71,475,318$ & 24.88 & 0.000 & 0.100 & 9.78 & 0.002 & 0.041 & 0.14 & 0.709 \\
\hline $884 \_200^{\mathrm{b}}$ & 6 & $42,689,435-42,689,555$ & 4.64 & 0.032 & 0.017 & 5.07 & 0.025 & 0.025 & 3.09 & 0.079 \\
\hline Sb6_342 & 7 & $38,823,193-38,823,478$ & 4.49 & 0.012 & 0.038 & 6.06 & 0.015 & 0.030 & 0.36 & 0.837 \\
\hline Sb6_34 & 8 & $61,802,592-61,802,795$ & 7.58 & 0.001 & 0.063 & 4.02 & 0.046 & 0.020 & 5.70 & 0.058 \\
\hline 835_200 & 10 & $56,491,522-56,491,702$ & 3.61 & 0.049 & 0.016 & 6.85 & 0.009 & 0.029 & 1.50 & 0.220 \\
\hline Four markers $^{c}$ & 3 & & 15.67 & 0.000 & 0.219 & 7.06 & 0.000 & 0.119 & & \\
\hline All markers & & & 8.15 & 0.000 & 0.251 & 3.82 & 0.000 & 0.122 & & \\
\hline
\end{tabular}

${ }^{a}$ Ccorresponds to SCAR_811; ${ }^{\mathrm{b}}$ corresponds to SCAR_884; ${ }^{\mathrm{c}}$ the four markers on chromosome $3 .{ }^{\mathrm{d}}$ The chromosome number and the position of the markers within the corresponding chromosomes (in bp range) were identified through BLAST (https://blast.ncbi.nlm.nih.gov/Blast.cgi) search of the sequences of the markers against the sorghum genome. The GenBank Accession number of chromosomes 3, 6, 7, 8 and 10 are NC_012872.2, NC_012875.2, NC_012876.2, NC_012877.2, NC_012879.2, respectively. Note: the position of SbMATE gene on chromosome 3 (NC_012872.2) is 71,105,461-71,108,054 bp 


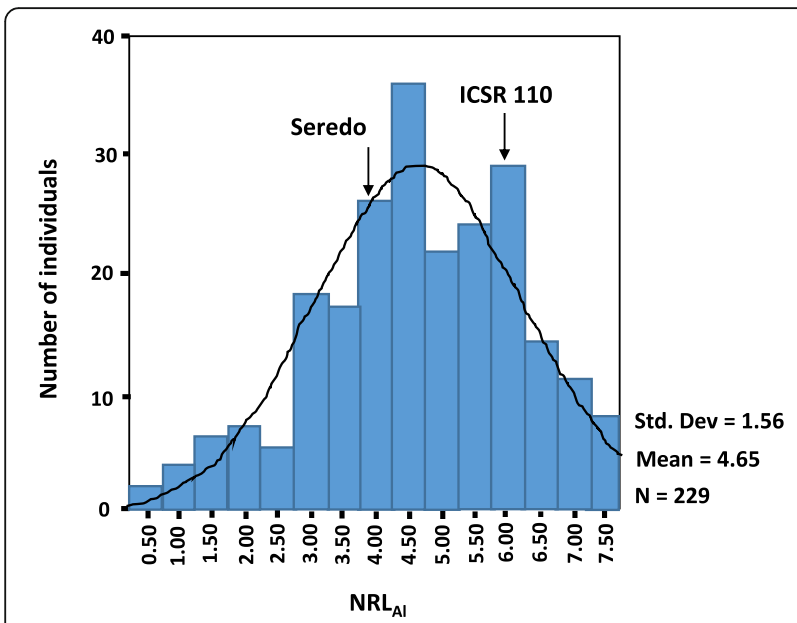

Fig. 1 Frequency distribution of $\mathrm{NRL}_{\mathrm{Al}}$ of $229 \mathrm{~F}_{2: 3}$ progeny derived from a cross between Seredo, an aluminium sensitive sorghum line, and ICSR 110, an aluminium tolerant line. The $N R L_{A l}$ mean values for Seredo and ICSR 110 were $3.8(n=40)$ and $6.0(n=40)$, respectively as shown by the arrows

Basic Local Alignment Search Tool (BLAST) was used to search the GenBank (https://www.ncbi.nlm.nih.gov/ genbank/) and the Gramene (http://www.gramene.org) databases to locate the genomic positions of these markers within the sorghum genome. The BLAST searching of 811_1400 marker sequence in the Gramene database resulted in a sorghum sequence that share 1386 bp (with $99.6 \%$ sequence identity) with 811 1400 on chromosome 3 at position 71,512,250-71,513,635 bp. The corresponding position of this marker on sorghum chromosome 3 (GenBank accession number NC_012872.2) is 71,473,923-71,475,318 bp (Table 2).

Two sequences that shared $116 \mathrm{bp}$ and $115 \mathrm{bp}$ (both with $100 \%$ sequence identity) with $884 \_200$ were found

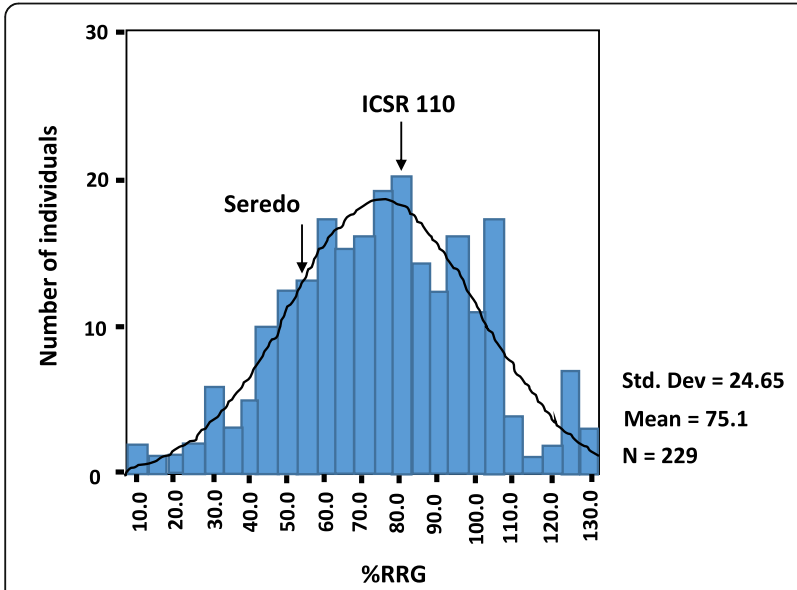

Fig. 2 Frequency distribution of \%RRG of $229 \mathrm{~F}_{2: 3}$ progeny derived from a cross between Seredo, an aluminium sensitive sorghum line, and ICSR 110, an aluminium tolerant line. The \%RRGs of the parental lines are shown by the arrows for comparison through BLAST searching of Gramene database. These sequences are located on chromosome 6 at positions 42,646,793-42,646,908 bp and 42,646,902-42,647,016 bp, respectively, and the two sequences together cover the whole sequence of the marker 884_200. These sequences have an overlapping sequence with a gene, Sb06g015330, that codes for putative uncharacterized protein Sb06g015330 (source: UniProtKB/TrEMBL; Acc: C5YFS2_ SORBI; cited at http://www.gramene.org). The corresponding position of marker 884 200 on sorghum chromosome 6 (GenBank accession number NC_012875.2) is 42,689,435$42,689,555$ bp (Table 2). Similarly, two sequences that shared 155 bp and 72 bp (with 92.9 and 98.6\% sequence identity, respectively) with $835 \_200$ were found through BLAST searching of Gramene database. These sequences are located on chromosome 10 at position 56,232,617$56,232,771$ bp and 56,232,771-56,232,842 bp, respectively. The corresponding position of marker 835_200 on sorghum chromosome 10 (GenBank accession number $N C_{-}$ 012879.2) is 56,491,522-56,491,702 bp (Table 2). Hence, markers 811_1400,884_200 and 835_200 are located on chromosomes 3, 6 and 10, respectively. Of these markers, 811_1400 and 884_200 were converted into SCAR markers SCAR_811 and SCAR_884, respectively.

The first attempt to develop SCAR marker based on the sequence of 811_1400 fragment was by using forward and reverse primers that were developed through extending the sequence of ISSR_811 primer. These primers amplified fragments of the same size in both parents and their progeny. DNA sequencing of the fragments from tolerant and sensitive parents revealed two SNP sites that differentiate the parents (Table 3). One of these SNPs was targeted to design the forward primer in order to get amplified product specific to the sensitive parent, Seredo. The use of a forward primer that included the SNP site and a reverse primer that was designed by extending the $I S S R \_811$ primer resulted in the development of a polymorphic marker, SCAR_811. Fig. 3 shows the SCAR_811 marker segregation in the $\mathrm{F}_{2: 3}$ progeny and parents. The Chi-square goodness-offit test showed Mendelian segregation of this marker among the $\mathrm{F}_{2: 3}$ progeny $\left(\chi^{2}=0.14 ; P=0.71\right.$; Table 2$)$. The sensitive parental line and most of the sensitive $F_{2: 3}$ progeny bear SCAR_811 whereas the marker is absent in the tolerant parent ICSR 110 and most of the tolerant progeny showing the association between the SCAR_811 marker and tolerance to $\mathrm{Al}$ toxicity. This marker explained $10 \%$ of the variation in $\mathrm{NRL}_{\mathrm{Al}}\left(R^{2}=0.10\right.$; $P<0.001)$ and $4 \%$ of $\% R R G\left(R^{2}=0.04 ; P<0.01\right)$ in the $\mathrm{F}_{2: 3}$ progeny (Table 2).

The primers for SCAR_ 884 were developed by excluding the first three nucleotides at the $5^{\prime}$-end of $I S S R \_884$ primer and extending the sequence at the 3 '-end. The 884 200 fragment was specific to ICSR 110 parental line. 


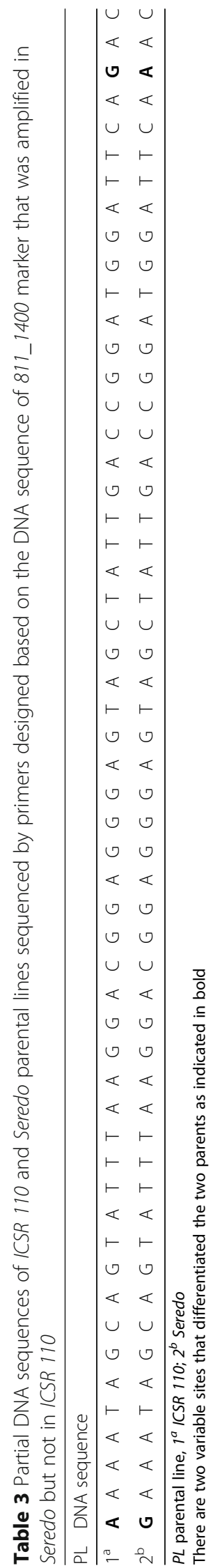




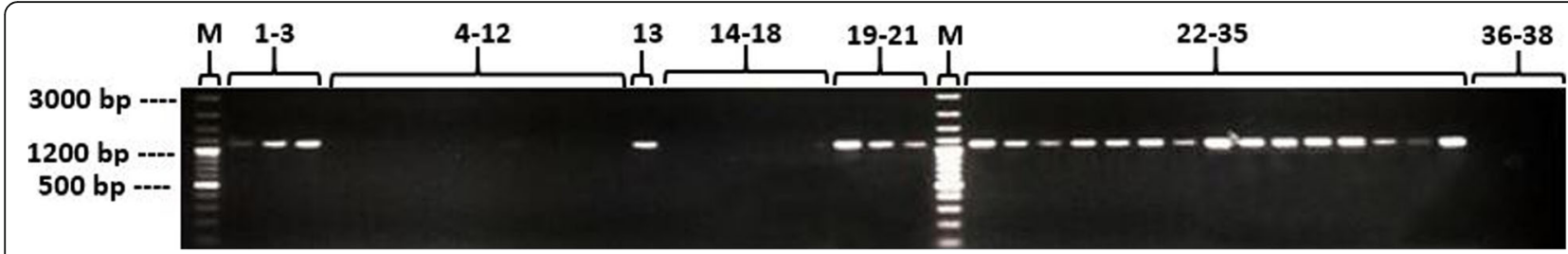

Fig. 3 Segregation of SCAR_811 marker in aluminium tolerant (lanes 4-18) and sensitive (lanes 22-35) $F_{2: 3}$ progeny. The $F_{1} S$ are on lanes 19-21 and the parental lines Seredo and ICSR 110 are on lanes $1-3$ and 36-38, respectively

However, the newly designed SCAR_884 primer-pairs amplified fragments both in Seredo and ICSR 110 but of different fragment sizes. Sequencing of these fragments revealed that the fragment from Seredo had a 220 bp insertion. All $\mathrm{F}_{1}$ individuals produced from the Seredo $x$ ICSR 110 crosses had both fragments and hence the SCAR_884 marker is co-dominant and can be used to differentiate homozygotes and heterozygotes at this locus. This marker showed significant association with Al tolerance $(P<0.05)$ when analyzed using both $\mathrm{NRL}_{\mathrm{Al}}$ $\left(R^{2}=0.017\right)$ and \%RRG $\left(R^{2}=0.025\right)$ indices.

Analysis of the parental lines and some of their $\mathrm{F}_{2: 3}$ progeny using STS markers M181 and CTG29 produced fragments of the same size for each marker, and could not be used to differentiate the tolerant and sensitive lines. Hence, the PCR products of the parental lines as well as five most tolerant and four most sensitive $F_{2: 3}$ progeny were sequenced for both markers in an attempt to identify useful sequence variation. The DNA sequences of marker M181 were identical for all genotypes sequenced whereas a two base pair indel (GA/-) that differentiated the sensitive and tolerant parents was observed in the case of CTG29 (Table 4). Based on these sequences, a new dominant marker, designated as
CTG29_3b (Table 2), was developed by designing a new forward primer that included the indel sequence. The CTG29_3b marker amplified by this forward primer and the CTG29 reverse primer was present in ICSR 110 and most tolerant $F_{2: 3}$ progeny and absent in Seredo and most sensitive $F_{2: 3}$ progeny. The association of this marker with $\mathrm{Al}$ tolerance when analyzed based on $\mathrm{NRL}_{\mathrm{Al}}\left(R^{2}=0.048\right)$ and \%RRG $\left(R^{2}=0.040\right)$ is significant $(P<0.005)$ (Table 2).

The BLAST searching of CTG29-3b sequence against the sorghum genome sequence at http://www.gramene.org identified a sequence that share 177 bp (with $100 \%$ sequence similarity) with CTG29-3b at position 70,979,101$70,979,277$ bp on chromosome 3 , in agreement with previous reports [23, 24]. The corresponding position of this marker on sorghum chromosome 3 (GenBank accession number NC_012872.2) is $70,939,651-70,939,834$ bp (Table 2). Overall, single marker analysis revealed that the mean net root length of the different genotypic groups for each of the four dominant markers (811 1400, 835 200, 884_200, CTG29_3b) was significantly different (Fig. 4).

In the case of SSR, polymorphism was detected in nine out of the 24 loci analyzed for the parents. Data analysis

Table 4 Partial DNA sequence of STS locus CTG29 showing indels that differentiated the aluminium tolerant $F_{2: 3}$ progenies (15r, 15A2, 21a, $15 \mathrm{~m}, 21 \mathrm{~h}, 15 \mathrm{v}$ and $42 \mathrm{C}$ ) and parental line ICSR 110 from aluminium sensitive $\mathrm{F}_{2: 3}$ progeny $(60 \mathrm{f}, 59 \mathrm{a}, 689,693)$ and parental line Seredo

\begin{tabular}{|c|c|c|c|c|c|c|c|c|c|c|c|c|c|c|c|c|c|c|c|c|c|c|c|c|c|c|c|c|c|c|c|c|c|c|c|c|c|c|c|}
\hline \multirow{2}{*}{$\frac{\text { Sample code }}{15 r}$} & \multicolumn{39}{|c|}{ DNA sequence } \\
\hline & A & $\mathrm{T}$ & A & $\mathrm{T}$ & $\mathrm{T}$ & A & $\mathrm{T}$ & $\mathrm{T}$ & A & A & A & A & C & $\mathrm{T}$ & G & $\mathrm{T}$ & G & $\mathrm{T}$ & G & A & $\mathrm{T}$ & A & $\mathrm{T}$ & A & G & C & G & $\mathrm{T}$ & G & A & G & C & G & T & G & G & A & & \\
\hline $15 A 2$ & A & $\mathrm{T}$ & A & $\mathrm{T}$ & $\mathrm{T}$ & A & $\mathrm{T}$ & $\mathrm{T}$ & A & A & A & $A$ & C & $\mathrm{T}$ & G & $\mathrm{T}$ & G & $\mathrm{T}$ & G & A & $\mathrm{T}$ & A & $\mathrm{T}$ & A & G & C & G & $\mathrm{T}$ & G & A & G & C & G & $\mathrm{T}$ & G & G & A & & \\
\hline $21 a$ & A & $\mathrm{T}$ & A & $\mathrm{T}$ & $\mathrm{T}$ & A & $\mathrm{T}$ & $\mathrm{T}$ & A & A & A & $A$ & C & $\mathrm{T}$ & G & $\mathrm{T}$ & G & $\mathrm{T}$ & G & A & $\mathrm{T}$ & A & $\mathrm{T}$ & A & G & C & G & $\mathrm{T}$ & G & A & G & C & G & $\mathrm{T}$ & G & G & A & A & \\
\hline $15 \mathrm{~m}$ & A & $\mathrm{T}$ & A & $\mathrm{T}$ & $\mathrm{T}$ & A & $\mathrm{T}$ & $\mathrm{T}$ & A & A & A & $A$ & C & $\mathrm{T}$ & G & $\mathrm{T}$ & G & $\mathrm{T}$ & G & A & $\mathrm{T}$ & $A$ & $\mathrm{~T}$ & A & G & C & G & $\mathrm{T}$ & G & A & G & C & G & $\mathrm{T}$ & G & G & A & A & \\
\hline $21 \mathrm{~h}$ & A & $\mathrm{T}$ & A & $\mathrm{T}$ & $\mathrm{T}$ & A & $\mathrm{T}$ & $\mathrm{T}$ & A & A & A & $A$ & C & $\mathrm{T}$ & G & $\mathrm{T}$ & G & $\mathrm{T}$ & G & A & $\mathrm{T}$ & A & $\mathrm{T}$ & A & G & C & G & $\mathrm{T}$ & G & A & G & C & G & $\mathrm{T}$ & G & G & A & A & \\
\hline $15 \mathrm{v}$ & A & $\mathrm{T}$ & A & $\mathrm{T}$ & $\mathrm{T}$ & A & $\mathrm{T}$ & $\mathrm{T}$ & A & A & A & $A$ & C & $\mathrm{T}$ & G & $\mathrm{T}$ & G & $\mathrm{T}$ & G & A & $\mathrm{T}$ & A & $\mathrm{T}$ & A & G & C & G & $\mathrm{T}$ & G & A & G & C & G & $\mathrm{T}$ & G & G & A & $A$ & \\
\hline $42 c$ & A & $\mathrm{T}$ & A & $\mathrm{T}$ & $\mathrm{T}$ & A & $\mathrm{T}$ & $\mathrm{T}$ & A & A & A & $A$ & C & $\mathrm{T}$ & G & $\mathrm{T}$ & G & $\mathrm{T}$ & G & A & $\mathrm{T}$ & A & $\mathrm{T}$ & A & G & C & G & $\mathrm{T}$ & G & A & G & C & G & $\mathrm{T}$ & G & G & A & $A$ & \\
\hline ICSR-110 & $A$ & $\mathrm{~T}$ & $A$ & $\mathrm{~T}$ & $\mathrm{~T}$ & A & $\mathrm{T}$ & $\mathrm{T}$ & A & $A$ & A & A & C & $\mathrm{T}$ & G & $\mathrm{T}$ & G & $\mathrm{T}$ & G & A & $\mathrm{T}$ & A & $\mathrm{T}$ & A & G & C & G & $\mathrm{T}$ & G & A & G & C & G & $\mathrm{T}$ & G & G & A & $A$ & \\
\hline Seredo & A & $\mathrm{T}$ & A & $\mathrm{T}$ & $\mathrm{T}$ & A & $\mathrm{T}$ & $\mathrm{T}$ & A & A & A & A & C & $\mathrm{T}$ & G & $\mathrm{T}$ & G & $\mathrm{T}$ & - & - & $\mathrm{T}$ & A & $\mathrm{T}$ & A & G & C & G & $\mathrm{T}$ & G & A & G & C & G & $\mathrm{T}$ & G & G & A & $A$ & \\
\hline $60 f$ & A & $\mathrm{T}$ & A & $\mathrm{T}$ & $\mathrm{T}$ & A & $\mathrm{T}$ & $\mathrm{T}$ & A & A & A & A & C & $\mathrm{T}$ & G & $\mathrm{T}$ & G & $\mathrm{T}$ & - & - & $\mathrm{T}$ & A & $\mathrm{T}$ & A & G & C & G & $\mathrm{T}$ & G & A & G & C & G & $\mathrm{T}$ & G & G & A & $A$ & \\
\hline $59 a$ & A & $\mathrm{T}$ & A & $\mathrm{T}$ & $\mathrm{T}$ & A & $\mathrm{T}$ & $\mathrm{T}$ & A & A & A & A & C & $\mathrm{T}$ & G & $\mathrm{T}$ & G & $\mathrm{T}$ & - & - & $\mathrm{T}$ & A & $\mathrm{T}$ & A & G & C & G & $\mathrm{T}$ & G & A & G & C & G & $\mathrm{T}$ & G & G & A & $A$ & \\
\hline 689 & A & $\mathrm{T}$ & A & $\mathrm{T}$ & $\mathrm{T}$ & A & $\mathrm{T}$ & $\mathrm{T}$ & A & A & A & A & C & $\mathrm{T}$ & G & $\mathrm{T}$ & G & $\mathrm{T}$ & - & - & $\mathrm{T}$ & A & $\mathrm{T}$ & A & G & C & G & $\mathrm{T}$ & $\mathrm{G}$ & $A$ & $G$ & C & G & $\mathrm{T}$ & $\mathrm{G}$ & $G$ & $\bar{A}$ & $A$ & \\
\hline 693 & $A$ & $\mathrm{~T}$ & $A$ & $\mathrm{~T}$ & $\mathrm{~T}$ & $A$ & $\mathrm{~T}$ & $\mathrm{~T}$ & $A$ & $A$ & $A$ & $A$ & C & $\mathrm{T}$ & $\mathrm{G}$ & $\mathrm{T}$ & $\mathrm{G}$ & $\mathrm{T}$ & - & - & $\mathrm{T}$ & $A$ & $\mathrm{~T}$ & $A$ & $\mathrm{G}$ & C & $\mathrm{G}$ & $\mathrm{T}$ & $\mathrm{G}$ & $A$ & $\mathrm{G}$ & C & G & $\mathrm{T}$ & $\mathrm{G}$ & $\mathrm{G}$ & A & A & \\
\hline
\end{tabular}



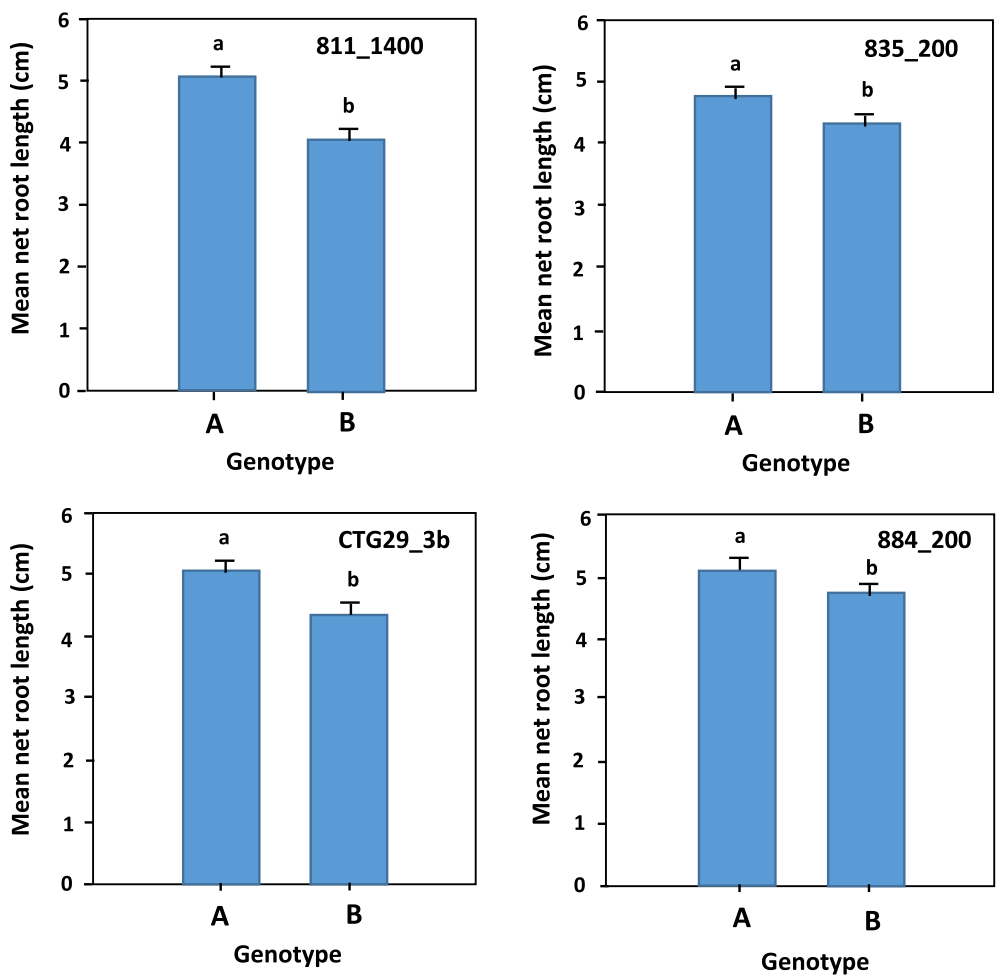

Fig. 4 Net root length of sorghum $F_{2: 3}$ progeny grown in the presence of $148 \mu \mathrm{M}$ aluminium based on the different genotypic classes for four dominant markers (811_1400,835_200, CTG29_36 and 884_200). For each locus, genotypes with different letters indicated on top of the bars were significantly different from each other in their tolerance to Al toxicity. The error bars represent standard error values

based on the $229 \mathrm{~F}_{2: 3}$ progeny together with the parental lines revealed that markers from four of the nine loci (Xtxp34, Sb6_34, Sb5_236 and Sb6_342) showed significant association with both $\mathrm{NRL}_{\mathrm{Al}}$ and \%RRG (Table 2; Fig. 5). The mean net root growth of the different genotypic classes, especially the homozygous classes were significantly different $(P \leq 0.05$; Fig. 5). For marker Xtxp34, the mean net root lengths of the three genotypic classes were distinctly different (Fig. 5). For markers Sb6_342 and Sb6_34, the heterozygous classes (AB) had mean net root lengths that were intermediate between the homozygous classes and were not significantly different from both homozygous parents $(P>0.05)$. Whereas the heterozygous class in marker Sb5_236 had mean net root length that was similar to net root length of the $\mathrm{B}$ homozygous class. The $\mathrm{NRL}_{\mathrm{Al}}$ phenotypic variance ( $R^{2}$ values) explained by these SSR markers were $14 \%$ for Xtxp34, 6\% for Sb6_34, 11\% for Sb5_236 and 4\% Sb6 342. For \%RRG, these values are 7, 2, 5 and $3 \%$, respectively (Table 2). The four markers on chromosome 3 (811_1400, CTG29_3b, Xtxp34 and Sb5_236) together explained 22\% of the variation in $\mathrm{NRL}_{\mathrm{Al}}$ and $12 \%$ of the variation in \%RRG $(P<0.001)$. The order of these markers on chromosome 3 (accession number NC_012872.2) is Sb5 236, Xtxp34, CTG29_3b and 811_1400 with 17,426 kbp, $1235 \mathrm{kbp}$ and $532 \mathrm{kbp}$ between them in that order (Fig. 6).
The closest marker to the SbMATE gene is CTG29_3b with $166 \mathrm{kbp}$ between them. Overall, the eight markers explained $25 \%$ of the variation in $\mathrm{NRL}_{\mathrm{Al}}$ and $12 \%$ of the variation in \%RRG $(P<0.001)$.

\section{Discussion}

Several molecular markers that are linked to aluminium tolerance genes have been identified in different crops. In rye, three AFLP markers [36] that are linked to gene Alt3 and two RAPD markers that were converted to SCAR markers [37], flank Alt1 gene. In maize, RFLP and SSR markers linked to Al tolerance QTLs have been reported [38]. Raman et al. [39] identified AFLP and microsatellite markers linked to the aluminium tolerance gene located on chromosome $4 \mathrm{H}$ in barley. The identification of molecular markers linked to $\mathrm{Al}$ tolerance in sorghum through genetic linkage, QTL and association mapping can accelerate the development of high yielding varieties that can withstand $\mathrm{Al}$ stress [14, 23-27]. Three ISSR (811_1400, 835_200 and 884_200), one STS (CTG29_3b) and four SSR (Xtxp34,Sb6_34,Sb5_236 and Sb6_342) markers showed significant association with aluminium tolerance in this study. Four of these markers (811_1400, CTG29_3b, Xtxp34 and Sb5_236) are located on chromosome 3 whereas markers $884 \_200$, 

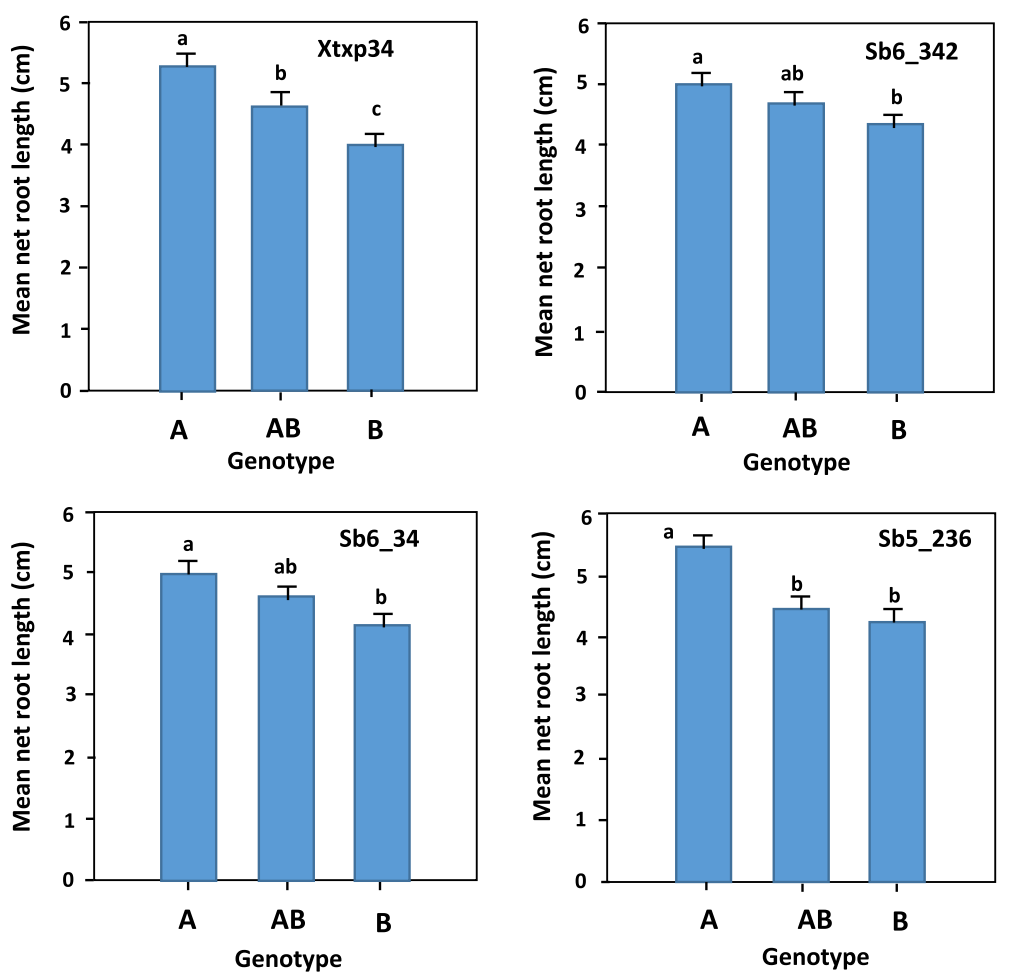

Fig. 5 Net root length of sorghum $F_{2: 3}$ progeny grown in the presence of $148 \mu \mathrm{M}$ aluminium based on the different genotypic classes of four codominant markers (Xtxp34, Sb6_342, Sb6_34 and Sb5_236). For each locus, genotypes that share the same letter indicated on top of the bars were not significantly different from each other in their tolerance to Al toxicity. The error bars represent standard error values

Sb6_342, Sb6_34 and 835_200 are located on chromosomes $6,7,8$ and 10 , respectively.

Genes that regulate Al tolerance in plants are shown to have different mode of actions. In rice, two genes that were referred to as sensitive to Al rhizotoxicity1 and 2 (STAR1 and STAR2) were reported to function as an ATP binding cassette (ABC) transporter and have significant contribution in $\mathrm{Al}$ tolerance [40]. Yamaji et al. [41] reported a C2H2-type zinc finger transcription factor, $\mathrm{Al}$ resistance transcription factor 1 (ART1), which regulates the expression of genes related to $\mathrm{Al}$ tolerance in rice, including STAR1 and STAR2. In line with these studies, the present study suggests the involvement of several genes in regulating $\mathrm{Al}$ tolerance in sorghum, as the markers that showed significant association with $\mathrm{Al}$ tolerance are located on five different chromosomes.

To date, only one Al tolerance locus, $A l t_{S B}$, which underlies the SbMATE gene in sorghum, has been identified and mapped to the terminal region of chromosome 3 and characterized in detail $[14,24,27]$. The SbMATE gene, codes for aluminium-activated citrate transporter that is highly expressed in root apices of aluminiumtolerant sorghum lines [14]. Caniato et al. [27] developed functional markers within the SbMATE gene that can be used for marker assisted selection for aluminium tolerance. In this study, two STS markers CTG29 and M181 that are located at $0.2 \mathrm{cM}$ and $0 \mathrm{cM}$ from Alt $_{S B}$ [14] were tested on $\mathrm{Al}$ tolerant and $\mathrm{Al}$ sensitive parental lines. STS M181 was monomorphic and could not be used in the genotyping of the Seredo x ICSR $110 \mathrm{~F}_{2: 3}$ progeny. The CTG29_3b dominant marker that was successfully developed using the nucleotide polymorphic site, showed significant association with Al tolerance and therefore suggests the role of $A t_{S B}$ in contributing to $\mathrm{Al}$ tolerance in the population studied.

SSRs can be used in cultivar genotyping, genotype identification, genetic diversity assessment and markerassisted breeding [27, 42]. Matos et al. [43] developed EST-SSRs that are associated with aluminium tolerance in rye. The SSR markers that showed significant association with $\mathrm{Al}$ tolerance in the present study are located on chromosomes 3,7 and 8. SSR marker Xtxp34 has been mapped to chromosome 3 [41, 44]. Sb6_342 was mapped to chromosome 7 [44] whereas Sb5_236 was mapped to chromosome 3 [41, 44], both of which were confirmed in the present study through BLAST searching of the sorghum genome. Similarly, the SSR marker Sb6_34 was located on chromosome 8 through BLAST search. These results indicate that in addition to SbMATE, other genes are involved in conferring $\mathrm{Al}$ tolerance in sorghum. Hence, there is a 


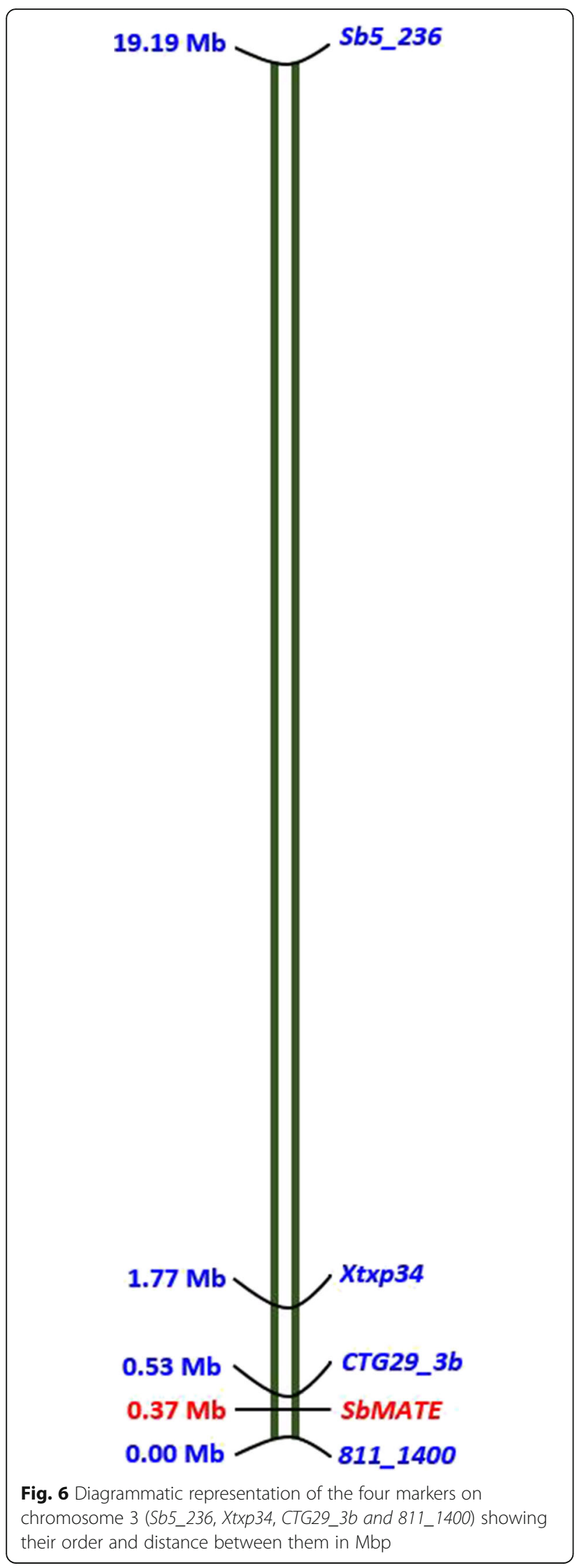

need to build on these findings by screening more markers close to the identified SSRs to ascertain the presence of new Al tolerance genes in these regions.

The ISSR_811 primer amplified a distinct locus of about1400 bp (811_1400) that differentiated the two parents and also showed a significant association with aluminium tolerance in the $\mathrm{F}_{2: 3}$ population studied. This marker is located close to SbMATE gene on chromosome 3 with about $366 \mathrm{kbp}$ between them (Fig. 6), and hence the phenotypic variance of the aluminium tolerance indices explained by this marker is most likely due to SbMATE gene. However, 811_1400 (SCAR_811) is also located very close to Calmodulin-Binding Transcription Activator 4 (CAMTA4) on this chromosome with only $7.3 \mathrm{kbp}$ between them. CAMTA2 is an activator of $\mathrm{Al}$ inducible $A L M T 1$ expression in Arabidopsis AtALMT1 [45]. Marker CTG29-3b is located closer to $S b M A T E$ gene (with only $166 \mathrm{kbp}$ between them) than marker 811_1400. However, 811_1400 explained more phenotypic variance $\left(R^{2}=0.10\right)$ than CTG29_3b $\left(R^{2}=0.04\right)$ in NRLAl, in this study. This may suggest the role of CAMTA4 in regulating SbMATE gene in sorghum.

The other two markers on chromosome 3 are located relatively far from SbMATE with 17.4 Mbp (Xtxp34) and 1.2 Mbp (Sb5_236) when compared with the locations of CTG29_3b and 811_1400. However, these markers explained higher phenotypic variance of the aluminium tolerance indices than CTG29_3b and 811_1400, which may suggest the presence of other genes around the vicinity of these markers that influence $\mathrm{Al}$ tolerance in sorghum. It is interesting to note that any pair of these markers on chromosome 3 explained more phenotypic variance than the variance they explained separately (data not shown) suggesting the independence of these markers in their contribution to Al tolerance. The four markers together explained $22 \%$ of the variance in $\mathrm{NRL}_{\mathrm{Al}}$ and $12 \%$ in \%RRG (Table 2), which is higher than the variance explained by any three or two or one of these markers. Hence, combined use of these markers together with markers on other chromosomes is a preferable approach in screening sorghum genetic resources for tolerance to Al toxicity.

The homeologous relationships between genomes of various cereals have been established [39, 46-50]. Previous studies [46-49] have shown that the long arm of wheat chromosome 4D (4DL) is partially homologous to the proximal portion of the short arm of rye chromosome 7R. Moreover, barley chromosome arm 4HL is homologous to the wheat chromosome arm 4DL [39] and a consensus grass comparative map has shown that rice chromosome 3 is homologous to wheat chromosome four [50]. An Aluminium-activated malate transporter 1like (ALMT1-like) gene (LOC110436609) is located at 
position $43,835,494-43,840,158$ bp on sorghum chromosome 6 (accession number Nc_012875.2). Marker 884_200 (SCAR_884) that showed significant association with aluminium tolerance in this study is located at position $42,689,435-42,689,555$ bp on this chromosome. Since this marker is located close to ALMT1-like gene with only about $1.1 \mathrm{Mbp}$ between them, and a strong positive correlation between $\mathrm{Al}$ induced malate exudation and relative net root growth has already been shown in sorghum [51], the significant association of this marker with aluminium tolerance is likely due to the role of ALMT1-like gene in Al tolerance. This also suggests that the sorghum ALMT1-like gene is an orthologue of ALMTI, as ALMTI gene that encodes $\mathrm{Al}$ activated malate transporter is known to regulate aluminium tolerance in wheat, barley and rye $[17,52,53]$. Hence, it is important that this gene is investigated in detail in relation to aluminium tolerance in sorghum.

\section{Conclusion}

The four markers on chromosome 3(811_1400 or SCAR_811, CTG29_3b, Xtxp34 and Sb5_236) suggest the role of $A l t_{S B}$ locus (SbMATE gene) in Al tolerance in the sorghum population used in the present study. However, their positions on chromosome 3 in relation to the position of SBMATE and the phenotypic variance explained by each of these markers suggest the presence of other genes on this chromosome that play a role in aluminium tolerance in sorghum. The presence of four other markers on different chromosomes that showed significant association with aluminium tolerance suggests the presence of additional genes that contribute to this trait in sorghum. Since the eight markers together explained higher phenotypic variance of the two Al tolerance indices than what explained by individual markers or any other combination of markers, the use of all markers in screening sorghum germplasm for $\mathrm{Al}$ tolerance is recommended.

\section{Acknowledgments}

This work was supported by the Swedish International Development Agency (SIDA/SAREC) through the BIO-EARN program and the Swedish University of Agricultural Sciences (SLU) through funding from the Swedish Ministry of Foreign Affairs as part of its special allocation on global food security (UD40). The authors are grateful to ICRISAT and MUSRT for providing the sorghum seeds. We confirm that none of the coauthors have conflict of interest to declare.

\section{Authors' contributions}

EJT conducted the lab work and data analysis and drafted the manuscript. SG and BAW were involved in selecting the parental lines and developing the mapping population. OAO was involved in the physiology aspects. AC contributed to the development of molecular markers. MG contributed to the lab work, data analysis and last stage revision of the manuscript. All co-authors contributed to the interpretation of the results and critically reviewed the manuscript at its initial stage and read and approved final version of manuscript for publication.

\section{Competing interests}

The authors declare that they have no competing interests.

\section{Publisher's Note}

Springer Nature remains neutral with regard to jurisdictional claims in published maps and institutional affiliations.

\section{Author details}

'Department of Biological Sciences, University of Eldoret, P.O. Box 1125-30100, Eldoret, Kenya. ${ }^{2}$ Rongo University College, P.O. Box 103-40404, Rongo, Kenya. ${ }^{3}$ Department of Plant Breeding, Swedish University of Agricultural Sciences, P.O. Box 101, SE-230 53 Alnarp, Sweden.

Received: 24 August 2017 Accepted: 3 April 2018

Published online: 13 April 2018

\section{References}

1. Kindraide TB, Parker DR. Assessing the phytotoxicity of mononuclear hydroxyl-aluminum. Plant Cell and Environ. 1989;12:479-87.

2. Ryan PR, Tyerman SD, Sasaki T, Furuichi T, Yamamoto Y, Zhang WH, Delhaize $E$. The identification of aluminium-resistance genes provides opportunities for enhancing crop production on acid soils. Exp Bot. 2011;62:9-20.

3. Famoso AN, Clark RT, Shaff JE, Craft E, Mccouch SR, Kochian LV. Development of a novel aluminium tolerance phenotyping platform used for comparisons of cereal aluminium tolerance and investigations into rice aluminium tolerance mechanisms. Plant Physiol. 2010;153:1678-91.

4. Horst WJ, Wang YX, Eticha D. The role of the root apoplast in aluminium-induced inhibition of root elongation and in aluminium resistance of plants: a review. Ann Bot. 2010;106:185-97.

5. Samac DA, Tesfaye M. Plant improvement for resistance to aluminium in acid soils-a review. Plant Cell Tissue Organ Cult. 2003;75:189-207.

6. Jansen S, Broadley MR, Robbrecht W, Smets E. Aluminium hyper accumulation in angiosperms: a review of its phylogenetic significance. Bot Rev. 2002;68:235-69.

7. Kanyanjua SM, Iren I, Wambua S, Nandwa SM. Acidic soils in Kenya: constraints and remedial options. KARI Technical Notes Series No. 2002:11.

8. Obura PA. Effects of soil properties on bioavailability of aluminium and phosphorus in selected Kenyan and Brazilian soils. PhD thesis, Purdue University. In: USA; 2008.

9. Wortmann CS, Mamo M, Abebe G, Mburu C, Kayuki KC, Letayo E, Xerinda S. Atlas of sorghum (Sorghum bicolor (L.) Moench) production in five countries of eastern Africa. The Board of Regents of the University of Nebraska, Lincoln, USA; 2006.

10. Hiradate $\mathrm{S}, \mathrm{Ma} \mathrm{JF}$, Matsumoto H. Strategies of plants to adapt to mineral stresses in problem soils. Adv Agron. 2007;96:65-132.

11. Naumann A, Horst WJ. Effect of aluminium supply on aluminium uptake, translocation and blueing of Hydrangea macrophylla (Thunb.) Ser. Cultivars in a peat-clay substrate. J Hort Sci Biotechnol. 2003;78:463-9.

12. Ma JF, Ryan PR, Delhaize E. Aluminium resistance in plants and the complexing role of organic acids. Trends Plant Sci. 2001;6:273-8.

13. Guo TR, Zhang GP, Zhang YH. Physiological changes in barley plants under combined toxicity of aluminium, copper and cadmium. Colloid Surface B. 2007;57:182-8.

14. Magalhaes JV, Liu J, Guimaraes CT, Lana UGP, Alves VMC, et al. A gene in the multidrug and toxic compound extrusion (MATE) family confers aluminium resistance in sorghum. Nat Genet. 2007;39:1156-61.

15. Cambraia J, Galvani FR, Estevao MM. Effects of aluminium on organic acid, sugar and amino acid composition of the root system of sorghum (Sorghum bicolor, L. Moench). J Plant Nutr. 1983;6:313-22.

16. Gonçales JFC, Cambraia J, Mosquim PR, Araújo EF. Aluminium effect on organic acid production and accumulation in sorghum. J Plant Nutr. 2005;28:507-20

17. Sasaki T, Yamamoto Y, Ezaki B, Katsuhara M, Ahn S, et al. A wheat gene encoding an aluminum-activated malate transporter. Plant J. 2004;37:645-53.

18. Furukawa J, Yamaji N, Wang H, Mitani N, Murata Y, et al. An aluminumactivated citrate transporter in barley. Plant Cell Physiol. 2007;48:1081-91.

19. Flores Cl, Clark RB, Gourley LM. Growth and yield traits of sorghum grown on acid soil at varied aluminum saturations. Plant Soil. 1988;106:49-57.

20. De Sousa CAN. Classification of Brazilian wheat cultivars for aluminium toxicity in acid soils. Plant Breed. 1998;117:217-21.

21. Bouton JH, Sumner ME. Alfalfa, Medicago sativa L., in highly weathered, acid soils. V. Field performance of alfalfa selected for acid tolerance. Plant Soil. 1983;74:431-6. 
22. Mariano ED, Keltjens WG. Evaluating the role of root citrate exudation as a mechanism of aluminium resistance in maize genotypes. Plant Soil. 2003;256:469-79.

23. Caniato FF, Guimaraes $C T$, Schaffert RE, Alves VMC, Kochian LV, Boren A, Klein PE, Magalhaes JV. Genetic diversity for aluminium tolerance in sorghum. Theor Appl Genet. 2007;114:863-76.

24. Magalhaes JV, Garvin DF, Wang Y, Sorrels ME, Klein PE, Schaffert RE, Li L, Kochian LV. Comparative mapping of a major aluminium resistance gene in sorghum and other species of the poaceae. Genetics. 2004;167:1905-14.

25. Caniato FF, Guimarães CT, Hamblin M, Billot C, Rami J-F, et al. The relationship between population structure and aluminum tolerance in cultivated sorghum. PLoS One. 2011;6(6):e20830. https://doi.org/10.1371/ journal.pone.0020830.

26. Leiser WL, Rattunde HFW, Weltzien E, Cisse N, Abdou M, Diallo A, Tourè AO, Magalhaes JV, Haussmann BIG. Two in one sweep: aluminum tolerance and grain yield in P-limited soils are associated to the same genomic region in west African sorghum. BMC Plant Biol. 2014;14:206.

27. Caniato FF, Hamblin MT, Guimaraes CT, Zhang Z, Schaffert RE, et al. Association mapping provides insights into the origin and the fine structure of the sorghum aluminum tolerance locus, AltSB. PLoS One. 2014:9(1):e87438. https://doi.org/10.1371/journal.pone.0087438.

28. Magnavaca R, Gardner C, Clark R. Comparison of maize populations for aluminium resistance in nutrient solution. In: Gabelman H, Loughman BC, editors. Genetic aspects of plant mineral nutrition. Dordrecht. Netherlands: Martinus Nijhoff; 1987. p. 189-99.

29. Ringo JH, Mneney EE, Onkware AO, Were BA, Too EJ, Owuoche JO, Gudu SO. Tolerance to Aluminium toxicity in Tanzanian sorghum genotypes. Afr Crop Sci J. 2010;18:155-64.

30. Bekele E, Geleta M, Dagne K, Jones AL, Barnes I, Bradman N, Thomas MG. Molecular phylogeny of genus Guizotia (Asteraceae) using DNA sequences derived from ITS. Genet Resour Crop Evol. 2007;54:1419-27.

31. Don R, Cox P, Wainwright B, Baker K, Mattick J. "Touchdown" PCR to circumvent spurious priming during gene amplification". Nucleic Acids Res 1991;19:4008.

32. Geleta M, Bryngelsson T. Inter simple sequence repeats (ISSR) analysis of genetic diversity and population genetic structure of Lobelia rhynchopetalum (Hochest.) Hemsel. (Campanulaceae). Hereditas 2009;146:122-130.

33. Sanguinetti CJ, Dias NE, Simpson AJ. Rapid silver staining and recovery of PCR products separated on polyacrylamide gels. BioTechniques. 1994;17:914-21.

34. Larkin MA, Blackshields G, Brown NP. Clustal W and Clustal X version 2.0. Bioinformatics. 2007;23:2947-8.

35. Hall TA. BioEdit: a user-friendly biological sequence alignment editor and analysis programme of windows 95/98/NT. Nucl Acids Symp Ser. 1999;41:95-8.

36. Miftahudin G, Scoles J, Gustaffson JP. AFLP markers tightly linked to the aluminium-resistance gene Alt3 in rye (Secale cereale L.). Theor Appl Genet 2002;104:626-631.

37. Gallego FJ, Calles B, Benito C. Molecular markers linked to the aluminium resistance gene Alt1 in rye (Secale cereale, L.). Theor Appl Genet 1998;97:1104-1109.

38. Ninamango-Cárdenas FE, Guimarães C, Martins P, Parentoni S, Carneiro N, Lopes M, Moro J, Paiva E. Mapping QTLs for aluminium resistance in maize. Euphytica. 2003;130:223-32.

39. Raman H, Moroni JS, Sato K, Read BJ, Scott BJ. Identification of AFLP and microsatellite markers linked with aluminium resistance gene in barley (Hordeum vulgare, L). Theor Appl Genet. 2002;105:458-64.

40. Huang CF, Yamaji N, Mitani N, Yano M, Nagamura Y, Ma JF. A bacterial-type $A B C$ transporter is involved in aluminum tolerance in rice. Plant Cell. 2009;21:655-67.

41. Yamaji N, Huang CF, Nagao S, Yano M, Sato Y, Nagamura Y, Ma JF. A zinc finger transcription factor ART1 regulates multiple genes implicated in aluminum tolerance in rice. Plant Cell. 2009;21:3339-49.

42. Gupta PK, Varshney RK. The development and use of microsatellite markers for genetic analysis and plant breeding with emphasis on bread wheat. Euphytica. 2000;113:163-85.

43. Matos M, Pérez-Flores V, Camacho MV, Pernaute B, Pinto-Carnide O, Benito C. Detection and mapping of SSRs in rye ESTs from aluminium-stressed roots. Mol Breed. 2007;20:103-15.

44. Menz MA, Klein RR, Mullet JE, Obert JA, Unruh NC, Klein PE. A high density genetic map of Sorghum bicolor (L) Moench based on 2926 AFLP, RFLP and SSR markers. Plant Mol Biol. 2002;48:483-99.
45. Tokizawa M, Kobayashi Y, Saito T, Kobayashi M, luchi S, et al. Sensitive to proton Rhizotoxicity1, calmodulin binding transcription activator 2, and other transcription factors are involved in aluminum-activated malate Transporter1 expression. Plant Physiol. 2015;167:991-1003.

46. Naranjo T, Fernández-Rueda P. Homoeology of rye chromosome arms to wheat. Theor Appl Genet. 1991;82:577-86.

47. Rognli OA, Devos KM, Chino CN, Harcourt RL, Atkinson MD, Gale MD. RFLP mapping of rye chromosome $7 R$ reveals a highly translocated chromosome relative to wheat. Genome. 1992;35:1026-31.

48. Devos KM, Atkinson MD, Chinoy CN, Francis HA, Harcourt RL, Koebner RMD, Liu CJ, Masojc P, Xie DX, Gale MD. Chromosomal rearrangements in the rye genome relative to that of wheat. Theor Appl Genet. 1993;85:673-80.

49. Naranjo T, Fernández-Rueda P, Maestra B. Chromosome rearrangements and homoeologous pairing: implications for the introgression of alien genes into wheat. In: Current topics in plant cytogenetics related to plant improvement Lelley T, editor. WUV-Univeitätsverlag, Austria;1997. p. 198-205.

50. Gale MD, Devos KM. Comparative genetics in the grasses. Proc Natl Acad Sci U S A. 1998:95:1971-4.

51. Cheprot RK, Matonyei TK, Maritim KK, Were BA, Dangasuk OG, Onkware AO, Gudu S. Physiological characterization of Kenyan sorghum lines for tolerance to aluminium. Int J Nat Sci Res. 2014;2:59-71.

52. Fontecha G, Silva-Navas J, Benito C, Metres MA, Espino FJ, Hernandez-Riquer MV, Gallego FJ. Candidate gene identification of an aluminum-activated organic acid transporter gene at the Alt4 locus for aluminum resistance in rye (Secale cereale, L). Theor Appl Genet 2007;114:249-260.

53. Collins NC, Shirley NJ, Saeed M, Pallotta M, Gustafson JP. An ALMTI gene cluster controlling aluminum resistance at the At/4 locus of rye (Secale cereale L.). Genetics 2008;179:669-682.

54. Smith JSC, Kresovich S, Hopkins MS, Mitchel SE, Dean RE, Woodman WL, Lee M, Porter K. Genetic diversity among elite sorghum inbred lines assessed with simple sequence repeats. Crop Sci. 2000;40:226-32.

55. Kong L, Dong J, Hart GE. Characteristics, linkage-map positions, and allelic differentiation of Sorghum bicolor $(\mathrm{L})$ Moech DNA simple sequence repeats (SSRs). Theor Appl Genet 2000;101:438-448.

\section{Ready to submit your research? Choose BMC and benefit from:}

- fast, convenient online submission

- thorough peer review by experienced researchers in your field

- rapid publication on acceptance

- support for research data, including large and complex data types

- gold Open Access which fosters wider collaboration and increased citations

- maximum visibility for your research: over $100 \mathrm{M}$ website views per year

At BMC, research is always in progress.

Learn more biomedcentral.com/submissions 